\title{
Social and Economic Consequences of Corporate Social and Environmental Disclosures in Nigeria
}

\author{
Odia J.O. (PhD) \\ Department of Accounting, University of Benin, Benin City; odiajames@yahoo.com \\ Imagbe V.U. \\ Bursary Department, University of Benin, Benin City; usunobunimagbe@gmail.com
}

\section{Doi:10.5901/mjss.2015.v6n6p177}

\begin{abstract}
This paper examined the consequences of corporate social and environmental disclosures in Nigeria (CSED). The research method was based on the survey of a sample of 351 shareholders, management and auditors. The results indicate a varying degree of differences with respect to stakeholders and gender with regard to the social and economic consequences of CSED. Specifically, there were significant differences among the stakeholders on the social and financial consequences of CSED in Nigeria. While the female respondents believed more on the social impacts of CSED, there was no gender difference regarding the financial consequences. Again, it was found that CSED is not used as profit-maximizing strategies by firms in Nigeria. It is concluded that corporate social and environmental disclosures have more social than financial imparts and hence support the legitimacy theory. The results have important implications for Nigerian companies as they formulate their socio-environmental strategy and communication. Therefore, it is recommended that companies should increase the disclosures on social and environment issues to improve their social and environmental performances which could eventually impact on their financial performances.
\end{abstract}

Keywords: Corporate social and environmental disclosures, social consequences, economic consequences, legitimacy theory

\section{Introduction}

Proponents of political-economy, legitimacy and stakeholder theories argue that companies (management) provide corporate social responsibility (CSR) information as part of their dialogue with the greater society (Gray, Kouhy \& Lavers,1995a).Even if the organization is complying with society's expectations, organizational legitimacy can be threatened if it fails to make disclosures of compliance with societal expectations (Newson \& Deegan,2002).According to the legitimacy theory, corporate social disclosure is used by companies to legitimate its activities in the face of societal pressures. Hence, companies need to demonstrate that they are complying with the 'social contract' by disclosing information in line with society's expectations (Dowling \& Pfeffer 1975,Lindblom 1994). Moreover, firms with threatened legitimacy make self-serving disclosures (Gray et al, 1995a,Hughes, Anderson \& Golden, 2001, Adams, 2004, Clarkson, Richardson \& Vasvari, 2008).

Basically, social and environmental disclosures are signals companies give to stakeholders in order to: increase their reputation and image (Friedman \& Miles,2001, Toms,2002), reduce environmental risks and construct competitive advantage (Kings,2002) and promote corporate sustainability (Kramer \& Porter,2006). Whereas some studies have examined whether there are significant differences in the requirements of corporate social disclosures based on respondents' demographics (Panwaar, Han \& Hansen.2010, De Villiers \& Van Staden, 2010), there is research gap on whether there are significant differences on the social and economic consequences of corporate social and environmental disclosures based on the legitimacy theory in Nigeria. Again, a lot of researches on CSED in Nigeria using the annual reports have examined areas like: the extent of CSED, determinants of CSED, the relation between financial performance and CSED a research gap exists as only few known studies have considered the social and economic consequences of CSED in Nigeria using the survey. Similarly, past researches suggested females have higher CSR expectations and there are gender differences in CSR (Schopler \& Bateson, 1965, Davidson \& Freudenburg,1996, Burton \& Hegarty, 1999, Diamantopoulos et al,2003, De Villiers et al (2010) but it is not known whether there are gender differences in relation to the social and economic consequences of CSED in a developing country like Nigeria. Therefore, the objective of this paper is to examine the perception of company's respondents on the social and economic consequences of CSED in Nigeria. The rest of the paper is divided into four sections. Section two dwells on the review of 
literature on the social and economic consequences of CSED. Section three outlines the methodology adopted for the study. Section four dwells on the analysis of data and discussion of the result. Section five is the conclusion.

\section{Literature Review and Hypotheses Development}

In this section, the state of CSED in Nigeria, the theoretical framework of legitimacy theory, the social and economic consequences of CSED and the hypotheses are considered.

\subsection{The state of CSED in Nigeria}

The need for CSR disclosures in Nigeria is due to the increased environmental problems such as urbanization, pollution, deforestation and environmental degradation (Okafor, Hassan \& Hassan, 2008) which have stirred up pressures on companies to begin to report on their corporate social responsibilities. Moreover, the country signing to the United Nations Global Compact (UNGC), stakeholders' pressure on companies to legitimize their operations, cross-border listing in and the need for corporate and environmental sustainability have increased the rate of disclosures. Although CSR is conjured in Nigeria to be philanthropic (Amaechi, Adi, Ogbechie \& Amao, 2006), the level of investments and involvement in CSR by companies is low (Akinyomi,2011, Alabi \& Ntukekpo,2012,Luper,2013).In Nigeria, CSED is voluntary and some of the regulations, standards and policies on social and environmental issues include the Federal Environmental Protection Agency (FEPA) Act of 2004 and the National Environmental Standards and Regulations Enforcement Agency (NESREA) Act of 2007.

A content analysis of CSED in the annual report shows an increasing interest in CSED by listed companies in Nigeria. Although over 80\% of listed companies in Nigeria currently provides CSED (Appah,2011; Odia,2013),the rate of corporate social disclosures (CSD) is low (Owolabi,2008; Enahoro,2009, Uwaloma,2011,Uwaloma \& Uadiale 2011, Asaolu, Agboola, Ayoola \& Salawu, 2011; Hashinu \& Ango,2012; Odia,2013). ).Again, employee and community information are the most disclosed information and the CSED is mostly rhetorics and general statements in Nigeria. Studies in other developing countries indicate lower CSED percentage such as: $26 \%$ in Malaysia and Singapore, less than 30\% in Malaysia, 6.4\% in Hong Kong ,33.96\% (Hassan,2010) and less than 50\% in Indonesia (Eriana et al, 2011)

\subsection{Legitimacy theory}

Legitimacy is defined as "a generalized perception or assumption that the actions of an entityare desirable, proper, or appropriate within some socially constructed system of norms, values, beliefs and definitions (Suchman,1995:574). Legitimacy theory suggests that CSER provides an important way of communicating with stakeholders and to convince them that the company is fulfilling their expectations (even when actual corporate behaviour remains at variance with some of these expectations (Branco \& Rodrigues,2007). It assumes that companies will make a rational and pragmatic strategic response to the public expectations in order to maintain some sorts of social compact with society. Legitimacy theory has been used to explain how companies respond in different ways to the social pressure, according to various factors that determine (the determinants) the level of social responsibility information (quantity and quality) provided by each company and the social and financial consequences thereby (Hassan,2010)

\subsection{Social consequences of CSED}

Various authors have claimed that social and environmental disclosures are signals companies give to stakeholders to increase their reputation (Friedman \& Miles,2001, Toms,2002, Hasseldine, Salama \& Toms 2005).Consequently, it is argued that company's reputation could influence CSD (Friedman \& Miles, 2001). Toms (2002) establishes that there is a strong linkage between qualitative disclosures and environmental reputation of the firm. Orlitzky, Schmidt \& Rynes (2003) find that the positive relationship between social disclosure and firm performance is mediated by the effect of reputation. A strong link has also been found between financial performance and reputation (Roberts \& Dowling, 2002, Toms, 2002). Hasseldine et al (2005) use the quality-signaling and resource-based view theory to extend Toms' (2002) work. Using a sample of 139 FTSE100 British companies, they find that the quality of environmental disclosures rather than the quantity disclosure has stronger effect on the creation of environmental reputation among executives and investor stakeholders group. Michelon (2007) examines the relationship between corporate reputation and CSD of 57 companies in the Dow Jones Sustainability Index (DJSI) as at 31 December 2003. He argues that corporate reputation can be considered either as a determinant or the result of CSD. Hassan (2010) finds that social (and environmental) disclosure significantly adds to 
the creation of social (and environmental) reputation and that the quality of CSD disclosure has a stronger effect on environmental reputation than quantity of CSD disclosure. These results are consistent with Toms (2002), Hasseldine et al (2005) and Odia (2013).

By disclosing information on social and environmental issues, companies can dealwith increased environmental risks such as: product liability, suit or recall cost, loss of public confidence, damaged reputation or corporate image and loss of market share, inimize the risk of powerful consumer boycotts (Adams,2002), communicate with the community and stakeholders (Anand,2002) and construct a competitive advantage (King,2002). Deegan, Rankin and Voght (2000) state companies use social disclosures as a tool to reduce the effects of events perceived to be unfavourable to their corporate image. Using survey and factor analysis, Hashimu and Ango (2012) examine the external stakeholders (customers and community members) of thirteen (13) multinational companies operating in Nigeria for over 15 years and find a significant relationship between social contributions by multinational companies in Nigeria and improved social status of the people. Companies use CSED create a positive reputation and ward off criticisms from pressure groups, (Gray, Bebbington \& Walters,1993; Neu, Warsame \& Pedwell,1998; Deegan, Rankin \& Voght, 2000), increase brand value, a healthier and safer workplace, stronger risk management and corporate governance, motivate people and community; enhance customer loyalty, confidence and trust of stakeholders, enhance public image and economic success, and improve social and environmental performances (Osemene, 2012).

\subsection{Economic or financial consequences of CSED}

There are mixed empirical results on the relationship between profitability and CSR disclosures. Although it has been advocated that the pursuit of CSR should not be at the expense of profits, from the theory of firm perspective firms engage in profit-maximizing CSR (McWilliams \& Siegel, 2000, Walden \& Siegel, 2008). Hassan (2010) finds no relationship between profitability measures and CSD. Hackston \& Milne (1996) find no significant association between the level of profitability and CSD for New Zealand companies. Bessong \& Tapang (2012) find a negative relationship between social cost and pollution cost on profitability of firms in Nigeria Nevertheless the areas that social and environment activity have direct financial consequences have increased such as: cost-saving nature, cost or liability avoidance, revenue generation and signal of best-in-class management practices (Hassan, 2010).Parsa \& Kouthy (2001) examine the relationship between CSD and different aspects of financial performance. The empirical results show that profitability and gearing have positive relationship with CSD. Moreover, Gozali, How and Verhoeven (2002) find companies with positive environmental disclosure perform significantly better in the market than companies that disclose negative environmental information. Gray et al (1995a \&b) contend that companies use their social reports to construct their relationship with others as they strive to create and maintain the conditions for their continued profitability and growth.CSR activities focusing on sustainability issues may lower costs and improve efficiencies, enhance company's stock price, making executives" stock and stock options more profitable and shareholders happier (Robins, 2011). Using the annual reports and regression analysis, a positive significant relationship has been found between companies' social disclosures and their financial performances in Nigeria (Ngwakwe, 2009; Kwambo (2011; Uadiale \& Fagbemi;2011). The results are consistent with the surveys findings of Amole, Adebiyi and Awolaja (2012), Akanbi and Ofoegbu (2012), Ismail and Adegbemi (2013) and Odia (2013).

\subsection{Gender and CSED}

With respect to CSR perceptions, Paul et al. (1997) and Burton and Hegarty (1999) conclude that females have higher CSR expectations than males. Generally, there are differences in attitudes of males and females towards the norm of social responsibility (Schopler \& Bateson, 1965). De Villiers et al (2010) find country and gender differences (with respect to Australian and female respondents) in shareholders' requirement for environmental disclosures in the US, UK and Australia. Moreover, females have higher concern regarding environmental issues (Davidson \& Freudenburg,1996) and hold stronger attitudes towards environmental quality than males (Diamantopoulos et al,2003).

\subsection{Research hypotheses}

Arising from the review of literature, the following null hypotheses are formulated:

Hypothesis 1: There is no significant difference in the perception of the respondents on the social consequences of CSED. of CSED

Hypothesis 2: There is no significant difference in the perception of the respondents on the financial consequences 
Hypothesis 3: There is no significant gender difference in the perception of the respondents on the financial consequences of CSED

Hypothesis 4: There is no significant gender difference in the perception of the respondents on the social consequences of CSED

\section{Methodology}

The survey method was employed for the study.The copies of questionnaire were administered to shareholders, management and auditors. The justification for their inclusion is the key roles of these groups in the financial reporting process in Nigeria. In order to gain the advantage of an in-depth study and effective coverage, samples for the survey were drawn using stratified random sampling from the six geopolitical zones in Nigeria. Due to the relatively low response rate envisage, a total of 1200 copies of the questionnaire were distributed in the six geopolitical zones in Nigeria. The questionnaires administered to shareholders, management and auditors were 450, 450 and 300 respectively. The management respondents include: company's CEOs, directors, senior management and accountants drawn from 30 companies listed in financial, petrochemical, construction, agriculture, breweries, conglomerates, health and pharmaceuticals sectors of the Nigerian Stock Exchange. Although 420 copies were returned, only 351 questionnaires representing $29.25 \%$ were duly completed and used for analysis.

The construction of our questionnaire follows: O' Dywer (2002), Doonan et al (2005), Panwaar et al (2010) and Wagner (2011) design. The questionnaire was divided into two parts. Part one comprises the personal information of the respondents such as: State/ region, gender, marital status, age, education and residential area. Part two dwells on the consequences of corporate social and environmental disclosures by companies. Most of the questions in part two follow the likert scale of five-point ranking scale as: very negative (1) negative (2) no effect (3) positive (4) and very positive (5) influence. The reliability test was conducted by using the Cronbach's alpha which was above 0.70 . Reliability of the research instrument items for social disclosures, environmental disclosures and financial consequences were 0.889 , 0.878 and 0.900 respectively. The ANOVA (F-test) was used to test for stakeholders and gender differences regarding the social and economic consequences of CSED.

\section{Data Analysis}

Table 1 shows the descriptive analysis of the respondents which comprises shareholders, management and auditors. Specifically the shareholders comprise members of Proactive Shareholders Association and other investors with shares in companies, the auditors are the audit partners from the big and non-big five audit firms and company's management include: CEOs, directors, managers and accountants. The demographical information shows respondents from a range of ages, educational background and marital status, both genders and a variety of occupations, but the majority are shareholders (51.9\%), male (61\%), married (64\%), and between $31-50$ years (58\%), graduates and post-graduates (84\%), and live in sub-urban and urban areas (90\%).

Table 1: Descriptive statistics

\begin{tabular}{|c|c|c|}
\hline & \multicolumn{2}{|c|}{ All Respondents } \\
\hline CATEGORIES OF RESPONDENTS & No & $(\%)$ \\
\hline Shareholders & 182 & 51.9 \\
\hline Management & 130 & 37.0 \\
\hline Auditors & 39 & 11.1 \\
\hline & 351 & 100 \\
\hline REGIONS & No & $(\%)$ \\
\hline North East & \multicolumn{2}{|c|}{-} \\
\hline North West & 35 & 10 \\
\hline North Central & 28 & 8 \\
\hline South East & 25 & 7 \\
\hline South West & 158 & 45 \\
\hline South South & 105 & 30 \\
\hline Total & 351 & $100 \%$ \\
\hline \multicolumn{3}{|l|}{ GENDER } \\
\hline Male & 213 & 61 \\
\hline Female & 138 & 39 \\
\hline Total & 351 & $100 \%$ \\
\hline
\end{tabular}




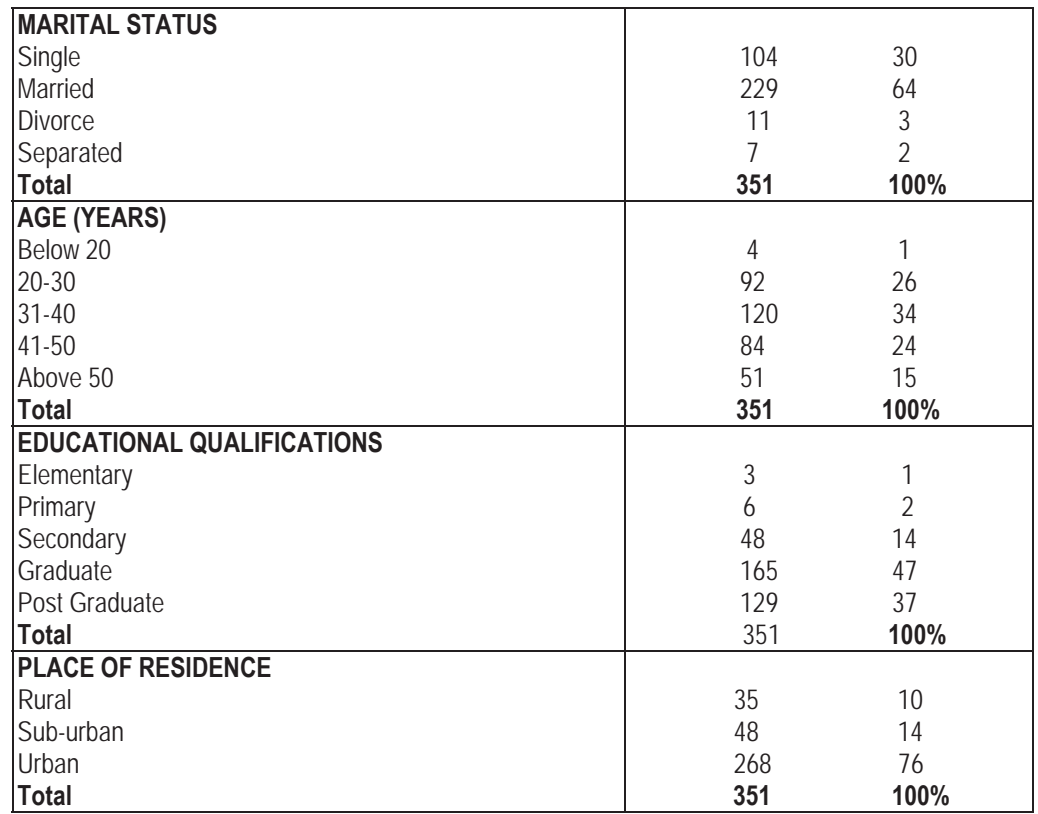

Field survey (2012)

\subsection{Consequences of corporate social and environmental disclosures}

Table 2 presents the responses on the social consequences of CSED. Regarding social consequences, about $80.1 \% \%$ and $82.9 \%$ of all respondents agree that CSED has positive impact on corporate reputation and image respectively. This indicates that companies which disclose CSED promote positively the public perception of the company's image and reputation as a good corporate citizen. Again, management and auditors (with $93 \%$ and $94 \%$ respectively) believe that CSED promote corporate reputation more than the shareholders (78.8\%). Moreover, $73.8 \%$ of all respondents agree that CSED can help open up new market opportunities for the company. Similarly, all respondents agree that CSED result in more satisfaction for workers (72.4\%), management (71.8\%) and owners (68.7\%). This means that companies which disclose CSED are bound to satisfy more their internal stakeholders. The reduced owners' satisfaction agrees with the agency conflicts between management and the owners that companies' management involvement in some corporate responsibilities may be seen by owners and other stakeholders as an attempt to expropriate company's resources and promote personal agenda (Friedman,1970., Davies, 1973, Wright \& Ferris,1997). Also the respondents agree that CSED impact on the company's social and environmental performance (70.7\%), productivity (66.6\%), improved insurance conditions (62.9\%) and reduced environmental risks (61\%).This result agrees with Osemene (2012) and Odia (2013) that CSR leads to more social benefits and reputation for an organization.

Table 2: Social consequences of CSED

\begin{tabular}{|l|l|c|c|c|c|c|c|}
\hline & $\begin{array}{c}\text { Overall } \\
\text { Mean }\end{array}$ & $\begin{array}{c}\text { Shareholders } \\
(4 \& 5)\end{array}$ & $\begin{array}{c}\text { Management } \\
(4 \& 5)\end{array}$ & $\begin{array}{c}\text { Auditor } \\
(4 \& 5)\end{array}$ & $\begin{array}{c}\text { All Respondents } \\
(4 \& 5)\end{array}$ & $\begin{array}{c}\text { Mean Ranking } \\
\text { (All respondents) }\end{array}$ \\
\hline 1 & & $\mathrm{~N}=182$ & $\mathrm{~N}=130$ & $\mathrm{~N}=39$ & $\mathrm{~N}=351$ & \\
\hline 2 & Manners satisfaction & 3.84 & $66.3 \%$ & $88.1 \%$ & $53.1 \%$ & $68.7 \%$ & 5 \\
\hline 3 & Worker satisfaction & 3.87 & $70.7 \%$ & $88 \%$ & $61.4 \%$ & $71.8 \%$ & 3 \\
\hline 4 & New market opportunities & 3.83 & $63.7 \%$ & $90.4 \%$ & $63.6 \%$ & $72.4 \%$ & 6 \\
\hline 5 & Improved Insurance condition & 3.94 & $66.9 \%$ & $91 \%$ & $79.7 \%$ & $73.8 \%$ & 1 \\
\hline 6 & Better access to bank loans & 3.83 & $58.7 \%$ & $82 \%$ & $53.5 \%$ & $62.9 \%$ & 6 \\
\hline 7 & Access to markets & 3.65 & $55.6 \%$ & $73 \%$ & $54.6 \%$ & $41 \%$ & 9 \\
\hline
\end{tabular}




\begin{tabular}{|l|l|c|c|c|c|c|c|}
\hline 8 & Environmental risks & 3.73 & $61 \%$ & $76 \%$ & $50 \%$ & $61 \%$ & 8 \\
\hline 9 & Social and environmental performance & 3.85 & $70 \%$ & $89.6 \%$ & $50 \%$ & $70.7 \%$ & 4 \\
\hline
\end{tabular}

Mean Values-Scoring: 1= Very negative; $3=$ No effect; $5=$ Very positive

Source: Field survey (2012)

With regard to the financial consequences in table 3, the proportion of all respondents agreement of CSED's effects are: corporate value (72\%), company's sales (70.4\%), company's profitability $(63.2 \%)$, cost savings $(62.7 \%)$ and share price $(60.1 \%)$. This is consistent with Garay and Font (2010) who find in a survey of 400 small and medium accommodation enterprises that the main reason for company acting responsibly is for altruistic and competitiveness reasons. Moreover, CSR activities are seen as becoming increasingly strategic as they affect the core business of the firm and its growth, profitability and survival (Kolk \& Pinkse,2008.,Verbeke,2009) as well as being a potential source of competitive advantage (Porter \& Kramer,2006). CSED is meant to show that the companies are complying with all the statutory regulations and laws such as FEPA Acts, NESREA Acts and environmental impart assessment (EIA) relating to social and environmental activities and to wade off public criticisms, attentions and social pressures on them. In other words, CSED is used as a legitimacy tool to legitimize company's operations.

The responses from the survey questionnaires indicate that financial performances proxied by share price, firm sales, profitability, corporate value and cost savings lag behind the social impacts and they are believed to be of less CSED impacts.

Table 3: Financial consequences of CSED

\begin{tabular}{|l|l|c|c|c|c|c|c|}
\hline & $\begin{array}{c}\text { Overall } \\
\text { Mean }\end{array}$ & $\begin{array}{c}\text { Shareholders } \\
(4 \& 5)\end{array}$ & $\begin{array}{c}\text { Management } \\
(4 \& 5)\end{array}$ & $\begin{array}{c}\text { Auditor } \\
(4 \& 5)\end{array}$ & $\begin{array}{c}\text { All Respondents } \\
(4 \& 5)\end{array}$ & $\begin{array}{c}\text { Mean Ranking } \\
\text { (All respondents) }\end{array}$ \\
\hline & & $\mathrm{N}=182$ & $\mathrm{~N}=130$ & $\mathrm{~N}=39$ & $\mathrm{~N}=351$ & \\
\hline 1 & Corporate reputation & 4.03 & $78.2 \%$ & $89 \%$ & $77.3 \%$ & $80.1 \%$ & 2 \\
\hline 2 & Corporate image & 4.19 & $78.8 \%$ & $94 \%$ & $93 \%$ & $82.9 \%$ & 4 \\
\hline 3 & Firm sales & 3.82 & $66.3 \%$ & $88.2 \%$ & $54.5 \%$ & $70.4 \%$ & 6 \\
\hline 4 & Firm profitability & 3.79 & $53.9 \%$ & $86 \%$ & $63.6 \%$ & $63.2 \%$ & 7 \\
\hline 5 & Short-term profit & 3.70 & $53.4 \%$ & $85 \%$ & $59.1 \%$ & $53.4 \%$ & 5 \\
\hline 5 & Corporate value & 3.82 & $68.3 \%$ & $88.9 \%$ & $72.7 \%$ & $72 \%$ & 9 \\
\hline 6 & Share price & 3.69 & $61.3 \%$ & $75 \%$ & $50 \%$ & $60.1 \%$ & 3 \\
\hline 8 & Cost savings & 3.67 & $54.5 \%$ & $85.1 \%$ & $52.3 \%$ & $62.7 \%$ & 3 \\
\hline 9 & Productivity & 3.89 & $61.8 \%$ & $85.3 \%$ & $58.1 \%$ & $66.4 \%$ & \\
\hline
\end{tabular}

Mean Values-Scoring: 1= Very negative; $3=$ No effect; $5=$ Very positive

Source: Field survey (2012)

In fact, the mean rankings in tables 3 and 4 shows that the greatest social and economic consequences of CSED are: (1) to improve corporate image (mean= 4.19), (2) corporate reputation (mean=4.03), (3) harness new market opportunities (3.94), (4) access to market, (5) improve productivity (3.89), (6) management satisfaction and (7) owners satisfaction. Specifically, the financial consequences of CSED such as: corporate value, firm sales, share price, firm profitability, cost saving and access to bank loan have low mean values. This indicates that the respondents consider CSED not to have direct impact on financial performance. In other words, CSED seems to have more social and legitimacy effects than financial impacts. One reason for the result may be the low interest for corporate sustainability reporting by listed companies in Nigeria as most investors are yet to require CSED in their investment decisions (Odia, 2009). Also, the result is consistent with the legitimacy theory that CSED is a legitimacy tool without direct economic benefits. Therefore, corporate social and environmental disclosures are not used as profit-maximizing strategies by listed firms.

\subsection{Test of hypotheses}

The ANOVA was used to test whether there are stakeholders (three groups of respondents) and gender differences among the on the financial and social consequences of CSED. 


\subsubsection{Financial and social consequences (Hypotheses 1 and 2)}

The result in table 3 shows that the management believes more than the other respondents that there is greater financial consequence of CSED. This tends to support Asaolu et al (2011) finding while companies in the oil and gas industry in Nigeria disclose extensively on the economic performance indicators in their CSR disclosures. The high management mean scores above the overall mean support Amole et al (2012), Akinpelu, Ogunbi, Olaniran and Ogunseye (2013) and Ismail et al (2013) that CSED is perceived by management to have positive financial consequences. However, the ANOVA test of hypothesis 1 shows that there are significant differences among the respondents on the financial consequences of CSED. This indicates CSED may not have financial consequences. This tends to support Kwambo (2011) and Odia (2013) that CSED has no direct financial benefits but inconsistent with the positive relationship found by Ngwakwe (2009) and Uadiale and Fagbemi (2011).

Table 3. Financial consequences of CSED

\begin{tabular}{|r|l|c|c|c|c|c|c|}
\hline & & $\begin{array}{c}\text { Overall } \\
\text { Mean }\end{array}$ & $\begin{array}{c}\text { Shareholder } \\
\text { Mean }\end{array}$ & $\begin{array}{c}\text { Management } \\
\text { Mean }\end{array}$ & $\begin{array}{c}\text { Auditors } \\
\text { Mean }\end{array}$ & ANOVA & Remark on H1 \\
\hline 1 & Firm sales & 3.82 & 3.63 & 4.18 & 3.55 & $16.471^{\star \star *}$ & Reject \\
\hline 2 & Firm profitability & 3.79 & 3.49 & 4.24 & 3.68 & $21.180^{\star \star \star}$ & Reject \\
\hline 3 & Short-term profit & 3.70 & 3.45 & 4.01 & 3.71 & $13.133^{\star \star \star}$ & Reject \\
\hline 4 & Corporate value & 3.82 & 3.65 & 4.09 & 3.73 & $10.716^{\star \star \star}$ & Reject \\
\hline 5 & Share price & 3.69 & 3.59 & 3.88 & 3.52 & $4.151^{\star \star}$ & Reject \\
\hline 6 & Cost savings & 3.67 & 3.43 & 4.06 & 3.41 & $16.699^{\star \star \star}$ & Reject \\
\hline 7 & Productivity & 3.89 & 3.61 & 4.32 & 3.65 & $19.413^{\star \star \star}$ & Reject \\
\hline 8 & New market opportunities & 3.94 & 3.66 & 4.31 & 3.95 & $14.440^{\star \star \star}$ & Reject \\
\hline 9 & Better access to bank loans & 3.65 & 3.49 & 3.91 & 3.43 & $5.562^{\star \star}$ & Reject \\
\hline 10 & Access to markets & 3.92 & 3.69 & 4.21 & 3.91 & $12.342^{\star \star *}$ & Reject \\
\hline
\end{tabular}

Mean Values-Scoring: 1= Very negative; $3=$ No effect; $5=$ Very positive

Again, the overall mean scores in table 4 shows the CSED is believed by all respondents to improve the corporate image and reputation, and reduce environmental risk. This agrees with Osemene (2012) and Odia (2013) that CSED help to improve company's reputation. However, the management believes that CSED has more social consequences than the shareholders and auditors. The ANOVA test of hypothesis 2 shows that there are significant differences among the respondents on the social consequences of CSED. The result indicates lack of agreement on the use of CSED to improve the social performances of Nigerian companies by stakeholders. Thus, hypothesis 2 is rejected.

Table 4. Social consequences of CSED

\begin{tabular}{|c|c|c|c|c|c|c|c|}
\hline & & $\begin{array}{l}\text { Overall } \\
\text { Mean }\end{array}$ & $\begin{array}{l}\text { Shareholder } \\
\text { Mean }\end{array}$ & $\begin{array}{l}\text { Management } \\
\text { Mean }\end{array}$ & $\begin{array}{l}\text { Auditors } \\
\text { Mean }\end{array}$ & ANOVA & Remark on $\mathrm{H} 2$ \\
\hline 1 & Corporate reputation & 4.01 & 3.87 & 4.33 & 3.71 & 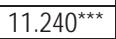 & Reject \\
\hline 2 & Corporate image & 4.19 & 3.94 & 4.47 & 4.28 & $17.071^{\star \star \star}$ & Reject \\
\hline 3 & Owners satisfaction & 3.84 & 3.73 & 4.11 & 3.45 & $15.031^{\star \star *}$ & Reject \\
\hline 4 & Management satisfaction & 3.87 & 3.76 & 4.11 & 3.64 & $10.507^{\star \star \star}$ & Reject \\
\hline 5 & worker satisfaction & 3.83 & 3.71 & 4.08 & 3.59 & $10.363^{\star \star \star}$ & Reject \\
\hline 6 & Improved Insurance condition & 3.83 & 3.54 & 4.12 & 4.02 & $3.075^{\star *}$ & Reject \\
\hline 7 & Environmental risks & 3.73 & 3.56 & 4.09 & 3.34 & $12.960^{* \star \star}$ & Reject \\
\hline 8 & Social and environmental performance & 3.85 & 3.75 & 4.15 & 3.27 & $16.189 * \star \star$ & Reject \\
\hline
\end{tabular}

\subsubsection{Gender differences (Hypotheses 3 and 4)}

The ANOVA results in table 5 shows that there are no significant differences between male and female respondents on the financial consequences of CSED. Thus hypothesis three $(\mathrm{H} 3)$ is accepted. But the result on the gender differences on the social consequences in table 6 shows that the null hypothesis $(\mathrm{H} 4)$ is accepted for the social consequences of management satisfaction, workers satisfaction and environmental risk. This result supports Schopler et al (1965), 
Diamantopoulos et al, (2003) and De Villiers et al (2010).

Table 5. Gender differences of finance consequences of CSED

\begin{tabular}{|l|l|c|c|c|c|c|}
\hline & & $\begin{array}{c}\text { Shareholder } \\
(\mathrm{t}-\text {-value })\end{array}$ & $\begin{array}{c}\text { Management } \\
(\mathrm{t}-\text {-value })\end{array}$ & $\begin{array}{c}\text { Auditors } \\
(\mathrm{t} \text {-value) }\end{array}$ & $\begin{array}{c}\text { ANOVA (F-value) } \\
\text { (All respondents) }\end{array}$ & $\begin{array}{c}\text { Remark on H3 } \\
\text { (All respondents) }\end{array}$ \\
\hline & Financial consequences & & & & & \\
\hline 1 & Firm sales & 0.563 & -0.302 & $-3.197^{\star \star \star}$ & 1.702 & Accept \\
\hline 2 & Firm profitability & 0.215 & 0.615 & $-2.343^{* *}$ & 1.773 & Accept \\
\hline 3 & Short-term profit & 0.574 & 0.563 & $-3.482^{\star \star *}$ & 0.844 & Accept \\
\hline 4 & Corporate value & -0.338 & -0.474 & -0.780 & 0.035 & Accept \\
\hline 5 & Share price & -0.449 & -0.199 & -1.234 & 0.106 & Accept \\
\hline 6 & Cost savings & -0.122 & 0.141 & -0.112 & 0.825 & Accept \\
\hline 7 & Productivity & 0.955 & -0.810 & -1.416 & 1.193 & Accept \\
\hline 8 & New market opportunities & 0.514 & 0.706 & -1.671 & 2.234 & Accept \\
\hline 9 & Better access to bank loans & -0.455 & -0.343 & 0.885 & 0.182 & Accept \\
\hline 10 & Access to markets & 0.902 & -0.138 & $-1.982^{*}$ & 1.806 & Accept \\
\hline
\end{tabular}

***, ${ }^{* *},{ }^{*}$ significant at $1 \%, 5 \%$ and $10 \%$ respectively

Table 6. Gender differences of social consequences of CSED

\begin{tabular}{|l|l|c|c|c|c|c|}
\hline & $\begin{array}{c}\text { Shareholder } \\
\text { (t-value) }\end{array}$ & $\begin{array}{c}\text { Management } \\
\text { (t-value) }\end{array}$ & $\begin{array}{c}\text { Auditors } \\
\text { (t-value) }\end{array}$ & $\begin{array}{c}\text { ANOVA (F-value) } \\
\text { (All respondents) }\end{array}$ & $\begin{array}{c}\text { Remark on H4 } \\
\text { (All respondents) }\end{array}$ \\
\hline & & & & & \\
\hline 1 & Cocial consequences & $1.650^{*}$ & -1.265 & 1.130 & $2.935^{*}$ & Reject \\
\hline 2 & Corporate reputation & 1.488 & -0.743 & -1.519 & $3.637^{*}$ & Reject \\
\hline 3 & Owners satisfaction & 0.905 & -0.086 & $2.639^{\star *}$ & $5.002^{\star *}$ & Reject \\
\hline 4 & Management satisfaction & -0.103 & -0.868 & -0.239 & 0.010 & Accept \\
\hline 5 & Worker satisfaction & 0.753 & -0.965 & 1.050 & 1.381 & Accept \\
\hline 6 & Improved Insurance condition & 0.491 & 0.679 & 1.111 & $3.637^{* *}$ & Reject \\
\hline 7 & Environmental risks & 0.344 & -0.400 & 1.370 & 1.804 & Accept \\
\hline 8 & Social and environmental performance & 1.501 & -0.069 & 1.612 & $5.177^{* *}$ & Reject \\
\hline
\end{tabular}

***, ${ }^{* *},{ }^{*}$ significant at $1 \%, 5 \%$ and $10 \%$ respectively

\section{Conclusion and Recommendation}

The purpose of the paper was to examine the perception of company's stakeholders on the social and economic consequence of CSED in Nigeria. Based on the survey of shareholders auditors and management, it was found that CSED has more social and legitimacy effects than financial impacts. In other words, the social consequences of CSED such as corporate reputation, social and environmental performance, owners, management satisfaction were found to have greater effects than the financial impacts like sales, profitability, market value and access to the market. There are also significant social and financial differences among the respondent groups on the social and financial CSED in Nigeria. Specifically, the management believes that CSED have more social and economic consequences than shareholders and auditors. Moreover there are significant gender differences with respect to social consequences of CSED. Therefore, it is recommended that companies should increase the disclosures of social and environmental information in order to improve their social and environmental performances. The regulatory bodies should ensure that companies comply with regulations and standards on with social and environment standards by disclosing CSED for users of their annual reports.

However, there are some limitations inherent in this study that may affect the generalization of the results. These include: First, the study was limited to the perceptions of shareholders, auditors and company's management. The views of other stakeholders like employees, regulatory authorizes, local communities and pressure groups are also very important. Moreover, the survey design was used for the study. We suggest further researches that include the other stakeholders and also using annual reports and quantitative data to examine the social and economic consequences of CSED in Nigeria as that could provide a robust and additional results. 


\section{References}

Adams, C.A. (2002).Internal organizational factors influencing corporate social and ethical reporting: Beyond current theorizing. Accounting, Auditing and Accountability Journal, 15,223 -250.

Adams, C. A. (2004). The ethical, social and environmental reporting- performance portrayal gap. Accounting, Auditing and Accountability Journal, 17(5), 731-757

Akanbi,P.A. \& Ofoegbu,O.O.(2012).Impact of corporate social responsibility on bank performance in Nigeria. Journal of US-China Public Administration, 9,374-383

Akinpelu,Y.A.,Ogunbi,O.J.,Olaniran,Y.A.\& Ogunseye, T.O. (2013). Corporate social responsibility activities disclosure by commercial banks in Nigeria. European Journal of Business and Management, 5(7),173-185.

Akinyomi, O.J. (2011).Survey of corporate social responsibility practices in Nigerian manufacturing sector. International Journal of Research Studies in Management

Alabi,O.F.\& Ntukekpo,S.S (2012).Oil companies and corporate social responsibility in Nigeria: An empirical assessment of Chevron's community development projects in the Niger Delta. British Journal of Arts and Social Sciences, 4(2),361-374

Amaeshi, K.M., Adi, B.C. Ogbechie, C \& Amao, O.O. (2006).Corporate social responsibility in Nigeria: Western mimicry or indigenous influence? Journal of Corporate Citizenship Winter, 24, 83-39

Amole, B. B., Adebiyi, S. O. \& Awolaja, A. M. (2012). Corporate social responsibility and profitability of Nigeria banks-A casual relationship. Research Journal of Finance and Accounting, 3(1),6-17.

Anand, V. (2002). Building blocks of corporate reputation- social responsibility initiatives. Corporate Reputation Review,5, 71-74.

Asaolu T. O., Agboola A. A., Ayoola T. J. \& Salawu M. K.(2011). Sustainability reporting in the Nigerian oil and gas sector. Proceedings of the Environmental Management Conference, Federal University of Agriculture, Abeokuta, Nigeria, 2011

Branco,M,C \& Rodrigues,L.L(2007) Issues in Social and Environmental Accounting: An overview. Issues in Social and Environmental Accounting,1(1),72-90 June

Burton, B.K \& Hegarty, W.H.(1999). Some determinants of students corporate social responsibility orientation, Business and Society,38(2),188-205

Clarkson, P. M., Li, Y., Richardson, G. D \& Vasvari, F. P. (2008).Revisiting the relation between environmental performance and environmental disclosure: An empirical analysis. Accounting, Organizations and Society, 33: 302-327

Davis. K. (1973). The case for and against business assumption of social responsibilities. Academy of Management Journal, 16, 312322.

Davidson,D.J \& Freudenburg,W.R.(1996). Gender and environmental risk concerns. Environment and Behavior,28(3),302-303

Deegan, C., Rankin,M. \& Voght, P. (2000). Firms' disclosures reactions to major social incidents: Australian evidence. Accounting Forum,24(1), 101-130.

De Villiers, C. \& Van Staden, C.J.(2010).Shareholders' requirements for corporate environmental disclosures: Across country comparison. The British Accounting Review, doi 10.1016/jbar 2010.08.002

Diamantopoulos,A Schlegelmilch,B.B., Sinkovics,R.R. \& Bohlen,G,M.(2003). A review of the evidence and an empirical investigation. Journal of Business Research,56(6),465-480.

Doonan,J., Lanoie,P \& Laplante, B (2005).Determinants of environmental performance in the Canadian pulp and paper industry: An assessment from inside the industry. Ecological Econmies, 55(1),73-84 October

Dowling, J. \& Pfeffer, J. (1975). Organisational legitimacy: Social values and organizational behavior. Pacific Sociological Review,18(1), 122-136.

Eriana,K.,Dudi, A.H \& Novan,B (2011).The relationship of profit and corporate social responsibility disclosure (Survey on manufacture industry in Indonesia).2nd International Conference on Business and Economic Research (2nd ICBER 2011) Proceedings

Friedman, M. (1970). The social responsibility of business is to increase its profits. New York Times Magazine,September 13, $122-126$.

Friedman, A.L. \& Miles S. (2001).Socially responsible investment and corporate social and environmental reporting in the UK: an exploratory study. British Accounting Review, 33( 4), 523-48.

Gozali,N.O., How, J.C.Y \& Verhoeven, P (2002).The economic consequences of voluntary environmental information disclosure. School of Economics and Finance, Curtin University of Technology, Western Australia

Gray, R., Bebbington, J. \& Walters, D. (1993). Accounting for environment -The greening of accountancy, Part II. The CACA, London.

Gray, R., Kouhy, R \& Lavers, S. (1995a). Corporate social and environmental reporting. A review of the literature and a longitudinal study of UK disclosure. Accounting, Auditing \& Accountability Journal, 8(2): 47-77

Gray, R., Kouhy, R. \& Lavers, S. (1995 b). Methodological themes. Constructing a research database of social and environmental reporting by UK companies. Accounting, Auditing \& Accountability Journal, 8(2),78.

Hackston,D. \& Milne, M.J. (1996). Some determinants of social and environmental disclosures in New Zealand companies. Accounting, Auditing and Accountability Journal,9(1),77- 108

Hashimu, B. \& Ango, N.A (2012). Multinational companies' corporate social responsibility performance in Lagos State, Nigeria: A quantitative analysis. European Journal of Globalization and Development Research, 5(1),247- 264

Hassan, N. T. (2010). Corporate Social Responsibility: An Examination of Framework of Determinants and Consequences. Doctoral Thesis, Durham University.Available at Durham E. Thesis outline: http://etheses.dur.ac.uk/480/

Hasseldine, J., Salama, A. I \& Toms, J. S. (2005). Quantity versus quality: The impact of environmental disclosures on the reputation of UK PIcs. The British Accounting Review, 37: 231-248. 
Hughes, S.B., Anderson, A \& Golden, S (2001). Corporate environmental disclosures: Are they useful in determining environmental performance? Journal of Accounting and Public Policy, 20,217-240

Ismail, O. F \& Adegbemi, B.O.O (2013).Does corporate social responsibility improve financial performance of Nigerian firms? Empirical evidence from triangular analysis. Pakistan Journal of Social Sciences,10(2), 92-98

King,A. (2002) How to get started in corporate social responsibility. Financial Management, Issue. October.

Kolk, A. \& Tulder, R. Van (2010). International business, corporate social reporting and sustainability development. International Business, 19(2), 11-125.

Kwanbo, M.L. (2011). An assessment of the effectiveness of social disclosure on earnings per share in Nigerian public corporations. World Journal of Social Sciences, 1(1),86-106

Line, M., Hawley, H. \& Krut,R. (2002). The development of Global environmental and social reporting. Corporate Environmental Strategy, $9(1), 69-78$

Lindblom, C.K.(1994).The Implications of organizational legitimacy for corporate social performance and disclosure. Paper presented at the Critical Perspective in Accounting Conference, New York U.S.A.

Luper,I.(2013). Rethinking banks corporate social responsibility (CSR) in Nigeria. International Journal of Financial Accounting,2,30-36

McWilliams, A. \& Siegel, D.(2001). Profit maximizing corporate social responsibility. Academy of Management Review, 26, 504-505

Michelon, G. (2007). Sustainability disclosure and reputation: A comparative study. Department of Economic Sciences University of Padua

Neu, D.,Warsame, H \& Pedwell, K. (1998). Managing public impression: Environmental disclosures in annual reports. Accounting Organization and Society, 23 (3), 265-282.

Newson, M. \& Deegan,C. (2002). An exploration of the association between global expectations and corporate social disclosures practices in Asia-Pacific Region. The International Journal of Accounting 37(2),183-213

Ngwakwe, C.C. (2009). Environmental responsibility and firm performance: Evidence from Nigeria. International Journal of Humanities and Social Sciences,3,2-22

Odia, J.O. (2009). Corporate social responsibity and stock prices: An empirical analysis of Nigerian listed companies.Management Sciences Review (MSR),2(1\&2)Jan/July,74-87

Odia, J.O. (2013). Corporate social and environmental disclosures in Nigeria.The determinants and consequences. Unpublished PhD Thesis, University of Benin,Benin City,Nigeria.

O'Dwyer, B. (2002). Managerial perceptions of corporate social disclosures.An Irish story. Accounting, Auditing and Accountability Journal 15 (3), 406-436

Orlitzky, M., Schmidt, F. \& Rynes, S. (2003). Corporate social and financial performance: A meta analysis. Organization Studies, 24(3), 403-41.

Okafor,E.E., Hassan, A.R \& Hassan, A.D (2008). Environmental issues and corporate social responsibility: The Nigeria experience. Journal of Human Ecology,23(2),101-107

Osemene, O.F (2012). Corporate social responsibility practices in mobile telecommunications industry in Nigeria. European Journal of Business and Management.4(8),149-157.

Robins R. (May, 2011).Does corporate social responsibility increase profits?Business Ethics

Parsa, S. \& Kouhy, R.(2001). Disclosure of social information by UK companies. A case of legitimacy theory. Accounting and Finance discussion papers, September (Middlesex University Business School).

Panwaar,R., Han, X \& Hansen, E (2010). A demographic examination of societal views regarding corporate social responsibility in the US forest products industry. Forest Policy and Economics,12(2),121-128 February.

Paul,K.,Zalka,L.M.,Downes,M.,Perry,S.\& Friday,S.(1997).U.S. consumer sensitivity to corporate social performance: development of a scale.Business and Society 36(4),408-418.

Porter, M.E \& Kramer, M.R. (2006).Strategy \& society: The link between competitive advantage and corporate social responsibility. Harvard Business Review, 84 (12), 1-14.

Roberts, R. W. \& Dowling, G.R. (2002).Corporate reputation and sustained superior financial performance. Strategic Management Journal, 23,1077-93

Schopler,J \& Bateson,N(1965).The Power of Dependence, Journal of Personality and Social Psychology, 2,247-254.

Solomon, A. \& Lewis, L. (2002). Incentives and disincentives for corporate environmental reporting. Business Strategy and the Environment, 11 (3),154-169.

Suchman, M.C.(1995).Managing legitimacy: Strategic and institutional approaches. Academy of Management Review, 20(3), 571-610.

Toms,J.S.(2002). Firm resources, quality signals and the determinants of corporate environmental reputation: Some UK evidence. British Accounting Review,34,257- 282

Uadiale, O. M. \& Fagbemi, T. O. (2011). Corporate social responsibility and financial performance in developing economies: the Nigerian experience. Paper delivered at New Orleans International Academic Conference.

Wagner, M. (2011). Corporate performance implications of extended stakeholder management: New insights on mediation and moderation effects. Ecological Economics,70(5),942-950, March

Waldman,D.A \& Siegel, D. (2008). Defining the socially responsible leader. The Leadership Quarterly,19 (1),117-131

Wright, P. \& Ferris, S. (1997). Agency conflict and corporate strategy: The effect of divestment on corporate value, Strategic Management Journal, 18, 77-83. 